\title{
Modelling and optimization of surfactant sensor response characteristics for the use in surface water and wastewater analysis
}

\begin{abstract}
The theoretical model of potentiometric titration curves of sodium dodecyl sulfate (anionic surfactant) was proposed and the response parameters of two surfactant sensors (commercial and self-made) were investigated. The both sensors were used to generate potentiometric experimental data, which were incorporated into the calculations using the mass and charge balance equations. The experimental data were compared with appropriate theoretical curves in which the sensor response parameters (sensor slope $S$, constant potential term $E_{o}$, potentiometric selectivity coefficient ( $\left.K_{i, j}^{\text {pot }}\right)$, sensor's membrane parameter (solubility product constant KS,CatAn) and analyte properties (activity ai, concentration ci) were estimated and optimized with Solver (Excel).

Key words: surfactant sensor, surfactants, potentiometry, modeling, solver
\end{abstract}

\section{INTRODUCTION}

Surfactants are used in almost all branches of industry and everyday life as home and industrial cleaning compounds, in cosmetics, pharmaceuticals, plating baths, petroleum products etc. Their waste belongs to the most widespread organic pollutants, representing a global environmental problem that demands the development of modern methodologies for their accurate determination.

The mostly used technique in ionic surfactant analysis is the two-phase titration method [1] with a mixed indicator, which suffers from many drawbacks [2].

Potentiometry with ion-selective electrodes (ISE) used as sensors is a simple, fast and inexpensive method for determining surfactants and avoids most of the limitations of classical titrimetric methods [3-9]. Flow-injection analysis was also used for potentiometric determination of anionic surfactants [10-12].

In these investigations, theoretical model for potentiometric titration curves of sodium dodecyl sulfate was proposed and their estimations and optimization of response parameters for two surfactant sensors are reported [13].

\section{EXPERIMENTAL}

\section{Reagents and materials}

The sensor response characteristics were investigated using sodium dodecylsulfate (SDS) and sodium dodecylbenzene sulfonate (SDBS).

Author's address: ${ }^{1}$ Institute of Public Health, Belgrade, Serbia, ${ }^{2}$ University in Belgrade, Faculty of Technology and Metallurgy, Serbia, ${ }^{3}$ Department of Chemistry, Josip Juraj Strossmayer University of Osijek, Croatia

Received for Publication: 10. 07. 2013.

Accepted for Publication: 23. 09. 2013.
Both chemicals were purchased from Fluka (Switzerland). Solutions of 1,3-didecyl-2-methylimidazolium chloride (DMIC, Fluka, Switzerland) and diisobutylphenoxyethoxy-ethyl-dimethyl-benzyl-ammonium chloride (Hyamine 1622, Merck, Germany) were used as the titrants.

\section{Apparatus and measurements}

An all-purpose titrator 794 Basic Titrino (Metrohm, Switzerland) combined with a Metrohm 806 Exchange unit (Metrohm, Switzerland) and controlled by the Metrodata Vesuv software was used as the dosing element to perform the potentiometric titrations.

A commercial solid state surfactant sensor (CS1) and a self-made liquid membrane surfactant sensor based on 1,3-didecyl-2-methylimidazolium tetraphenylborate (DMI-TPB) ion-exchange complex, which was used for the preparation of the PVC-based sensing membrane [8]. A silver/silver (I) chloride reference electrode (Metrohm, Switzerland), reference electrolyte sodium chloride solution $(c=3 \mathrm{M})$, was used as one reference.

\section{Optimization strategy using Solver}

Solver is a spreadsheet optimization modeling system incorporated into Microsoft Excel for Windows. It was used to compare an array of data predicted by the model with an initial set of parameter values over a range of dependent variable values with a set of experimental data. The macro SolvStat [15] provided the regression statistics for Solver by calculation of the standard deviations of the parameters, correlation coefficients and standard errors of the y estimate $\mathrm{SE}(\mathrm{y})$. 


\section{RESULTS AND DISCUSSION}

Anionic surfactants (An-) are usually titrated with an ion of opposite charge (Cat + ), thereby forming slightly sol=uble ion associates:

$$
\mathrm{Cat}^{+}+\mathrm{An}^{-} \leftrightharpoons \mathrm{CatAn}
$$
(1):

Its solubility product can be derived from Eq.

$$
K_{\mathrm{S}, \mathrm{CatAn}}=\left[\mathrm{Cat}^{+}\right] \times\left[\mathrm{An}^{-}\right]
$$

The mass balance for the analyte (An-):

$$
\left[\mathrm{An}^{-}\right]+[\text {CatAn }]+P_{\text {CatAn }}=C_{\mathrm{s}} \times \frac{V_{\mathrm{s}}}{\left(V_{\mathrm{s}}+V_{\mathrm{t}}\right)}
$$

where $V_{s}$ is the sample volume containing an analyte concentration of $C_{S}$.

The mass balance for the titrant (Cat + ):

$$
\text { Cat+] }+[\text { CatAn }]+\text { PCatAn }=\mathrm{Ct} \frac{V_{\mathrm{t}}}{\left(V_{\mathrm{s}}+V_{\mathrm{t}}\right)}
$$

where $V_{t}$ is the titrant volume with a concentration of $C_{t}$, [CatAn], is the equilibrium concentration of CatAn in the solution, and $P_{\text {CAtAN }}$ is the concentration of analyte (An-) or titrant (Cat +$)$ removed by the precipitation of CatAn. By subtracting (4) from (3) and after rearrangement the following equation is obtained:

$$
V_{\mathrm{t}}=V_{\mathrm{s}} \times \frac{\left(C_{\mathrm{s}}+\left[\mathrm{Cat}^{+}\right]-\left[\mathrm{An}^{-}\right]\right)}{\left(C_{\mathrm{t}}-\left[\mathrm{Cat}^{+}\right]+\left[\mathrm{An}^{-}\right]\right)}
$$

By substituting $\left[A n^{-}\right]=\frac{K_{s, \text { CatAn }}}{\left[\mathrm{Cat}^{+}\right]}$from Eq. (2) into Eq. (6), the following expression, which describes the course of the titration, is obtained:

$$
V_{\mathrm{t}}=V_{\mathrm{s}} \times \frac{\left(\mathrm{C}_{\mathrm{s}}+\left[\mathrm{Cat}^{+}\right]-\frac{K_{\mathrm{S}, \mathrm{CatAn}}}{\left[\mathrm{Cat}^{+}\right]}\right)}{\left(C_{\mathrm{t}}-\left[\mathrm{Cat}^{+}\right]+\frac{K_{\mathrm{S}, \mathrm{CatAn}}}{\left[\mathrm{Cat}^{+}\right]}\right)}
$$

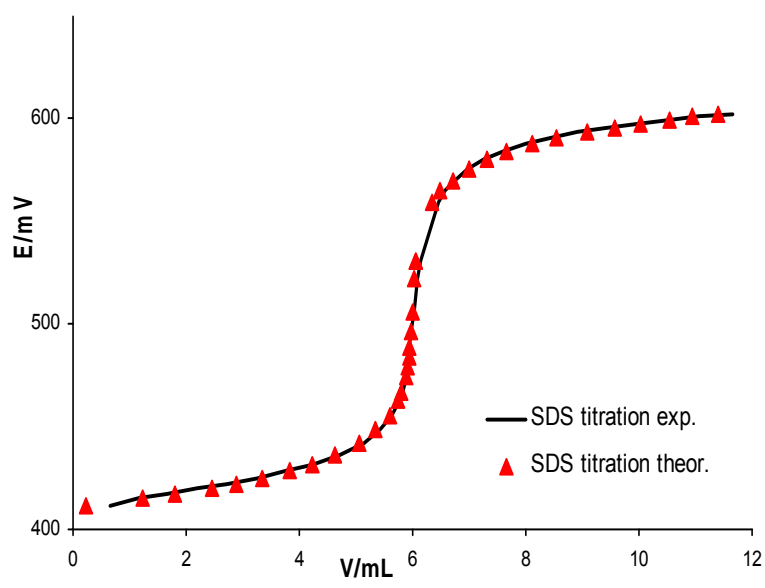

\begin{tabular}{|c|c|c|c|c|c|c|}
\hline \multicolumn{7}{|c|}{ Potentiometric titration data and model parameters (titration of SDS with Hyamine) } \\
\hline & & & & & \multicolumn{2}{|c|}{ Model parameter } \\
\hline $\mathrm{Vs} / \mathrm{mL}$ & 70 & & & & $\mathrm{Cs}(\mathrm{mol} / \mathrm{L})$ & $3,431 \mathrm{E}-04$ \\
\hline $\mathrm{Ct}(\mathrm{mol} / \mathrm{L})$ & $4,000 \mathrm{E}-03$ & & & & E0 & 735,761875 \\
\hline \multirow[t]{3}{*}{ Sensor } & CS-1 & $\mathrm{CHy}+=$ & $10 \exp ((\mathrm{E}-\mathrm{E} 0) / \mathrm{S})$ & & $\mathrm{s}$ & 37,308722 \\
\hline & & & & & Ks & $6,8208 \mathrm{E}-13$ \\
\hline & & & & & pKs & 12,166167 \\
\hline $\mathrm{Vt} / \mathrm{mL}$ & $\mathrm{E} / \mathrm{mV}$ & $(E-E 0) / S$ & $\mathrm{CHy}+/(\mathrm{mol} / \mathrm{L})$ & $\mathrm{pHy}$ & $(\mathrm{Vt})$ model./mL & SR \\
\hline 0,000 & 404,3 & $-8,884299$ & $1,3052 \mathrm{E}-09$ & 8,8843 & 0,136 & 0,018496 \\
\hline 1,666 & 417,3 & $-8,535855$ & $2,9116 \mathrm{E}-09$ & 8,5358 & 1,800 & 0,017979 \\
\hline 2,198 & 420,2 & $-8,458125$ & $3,4823 \mathrm{E}-09$ & 8,4581 & 2,457 & 0,067089 \\
\hline \multirow[t]{2}{*}{2,708} & 422,4 & $-8,399158$ & $3,9887 \mathrm{E}-09$ & 8,3991 & 2,889 & 0,032767 \\
\hline & & & & & ssr & 0,562095 \\
\hline
\end{tabular}

Figure 1 - Comparison of experimental and modeled potentiometric titration curves of SDS with Hyamine using CS-1 sensor.

Table 1 - The potentiometric titration data (partial) and model parameters for the titration of SDS with Hyamine using CS-1 sensor 


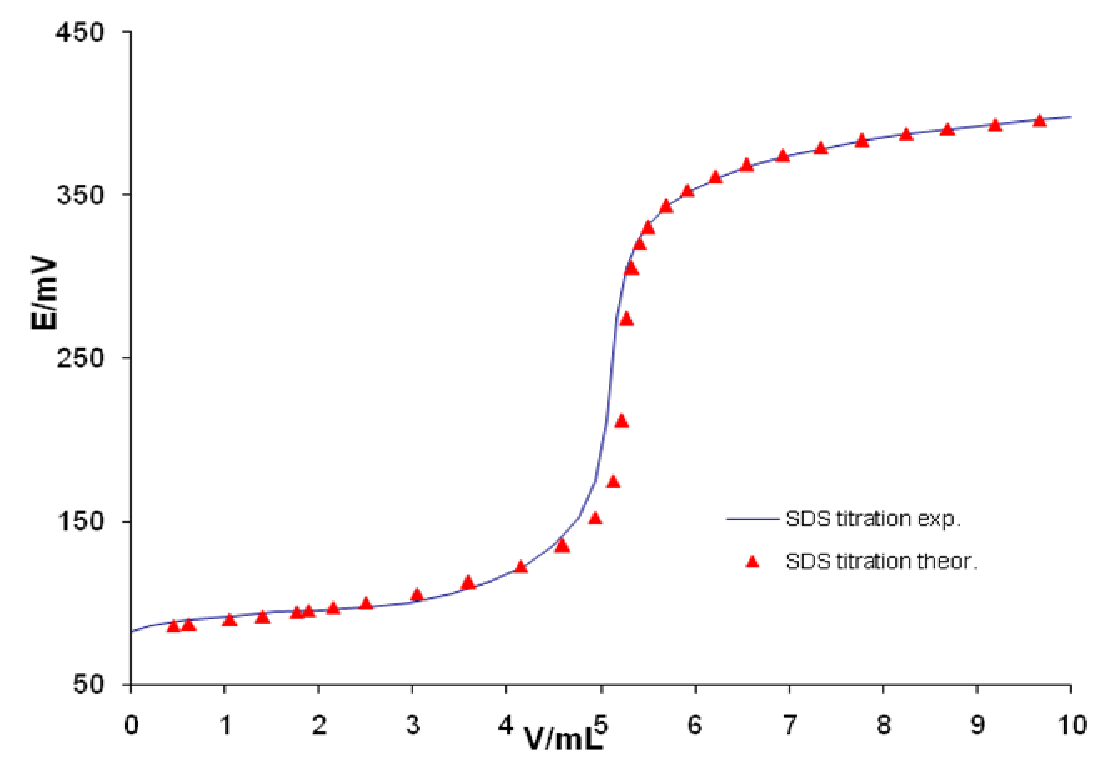

Figure 2 - Comparison of experimental and modeled potentiometric titration curves of SDS with Hyamine using DMI-TPB sensor

Table 2 - The potentiometric titration data (partial) and model parameters for the titration of SDS with Hyamine using DMI-TPB sensor

\begin{tabular}{|c|c|c|c|c|c|c|}
\hline \multicolumn{6}{|c|}{ Potentiometric titration data and model parameters (titration of SDS with Hyamine) } \\
\hline & & & & & \multicolumn{2}{c|}{ Model parameter } \\
\hline $\mathrm{Vs} / \mathrm{mL}$ & 55 & & & & $\mathrm{Cs}(\mathrm{mol} / \mathrm{L})$ & $3,705 \mathrm{E}-04$ \\
\hline $\mathrm{Ct}(\mathrm{mol} / \mathrm{L})$ & $4,000 \mathrm{E}-03$ & & & $\mathrm{E} 0$ & 604,396048 \\
\hline Sensor & $\mathrm{DMI}-\mathrm{TPB}$ & $\mathrm{CHy}+=$ & $10 \exp ((\mathrm{E}-\mathrm{E} 0) / \mathrm{S})$ & & $\mathrm{S}$ & 58,463954 \\
\hline & & & & & $\mathrm{Ks}$ & $3,91 \mathrm{E}-13$ \\
\hline & & & & & $\mathrm{pKs}$ & 12,407278 \\
\hline $\mathrm{Vt} / \mathrm{mL}$ & $\mathrm{E} / \mathrm{mV}$ & $(\mathrm{E}-\mathrm{E} 0) / \mathrm{S}$ & $\mathrm{CHy}+/(\mathrm{mol} / \mathrm{L})$ & $\mathrm{pHy}$ & $(\mathrm{Vt}) \mathrm{model} / \mathrm{mL}$ & $\mathrm{SR}$ \\
\hline 0,000 & 82,3 & $-8,930221$ & $1,1743 \mathrm{E}-09$ & 8,9302 & 0,253 & 0,064009 \\
\hline 4,177 & 122,7 & $-8,239197$ & $5,7650 \mathrm{E}-09$ & 8,2391 & 4,142 & 0,001215 \\
\hline 4,492 & 135,3 & $-8,023679$ & $9,4693 \mathrm{E}-09$ & 8,0236 & 4,536 & 0,001919 \\
\hline 4,752 & 152,5 & $-7,729481$ & $1,8643 \mathrm{E}-08$ & 7,7294 & 4,841 & 0,007913 \\
\hline
\end{tabular}

The experimental data were compared with the appropriate theoretical curves in which the sensor response parameters (slope $S$, constant potential therm E0) and unknown analyte properties (sample concentration Cs, solubility product constant $\left.K_{s, \text { CatAn }}\right)$ were optimized using Solver (Excel).

A part of the spreadsheets displaying the potentiometric titration data and calculated model parameters are shown in Tables 1 and 2. The potentiometric titration curves after the optimization procedure are shown in Figures 1 and 2.

\section{CONCLUSIONS}

Theoretical models for the potentiometric titration curves of anionic surfactants have been proposed. A commercial sensor and one self-made sensor of the own construction were used for all the measurements. The generated experimental data were compared with appropriate theoretical curves in which the unknown properties (slope, constant potential term, solubility product constant, and analyte concentration) were optimized using Solver (Excel). The proposed methodology gives the insight in the sensor condition and also 
contributes the membrane optimization by selection of the proper ion associate, which is predominantly responsible for the sensor sensitivity, which is important for determination of anionic surfactants in surface water and wastewater.

\section{REFERENCES}

[1] V. W. Reid, G. F. Longman, E. Heinerth: Tenside 4 (1967) 292

[2] W. S. Selig: Fresenius Z. Anal. Chem., 329 (1987) 486.

[3] B. Kovács, B. Csóka, G. Nagy, A. Ivaska: Anal. Chim. Acta 437 (2001) 67.

[4] R. Matešić-Puač, M. Sak-Bosnar, M. Bilić, B. S. Grabarić: Sens. Actuators B, 106 (2005) 221.

[5] J. Sánchez, M. del Valle: Crit. Rev. Anal. Chem., 35 (2005) 15.
[6] M. Sak-Bosnar, R. Matešić-Puač, D. Madunić-Čačić, Z. Grabarić: Tenside Surf. Det., 43 (2006) 82.

[7] D. Madunić-Čačić, M. Sak-Bosnar, R. Matešić-Puač, Z. Grabarić: Sensor Lett., 6 (2008) 339.

[8] D. Madunić-Čačić, M. Sak-Bosnar, M. Samardžić and Z. Grabarić: Sensor Lett., 7 (2009) 50.

[9] D. Madunić-Čačić, M. Sak-Bosnar, R. Matešić-Puač: Int. J. Electrochem. Sci., 6 (2011) 240.

[10] S. Martínez-Barrachina, J. Alonso, LI. Matia, R. Prats, M. del Valle: Anal. Chem., 71 (1999) 3684.

[11] T. Masadome, S. Kugoh, M. Ishikawa, E. Kawano, S. Wakida: Sensors and Actuators B, 108 (2005) 888.

[12] S. Martínez-Barrachina, M. del Valle: Microchem. J., 83 (2006) 48.

[13] E. J. Billo: Excel for Chemists, Wiley, New York (2001).

\section{IZVOD}

\section{MODELOVANJE I OPTIMIZOVANJE ODRŽIVIH KARAKTERISTIKA TENZIDNOG SENZORA ZA KORIŠĆENJE PRI ANALIZI POVRŠINSKIH I OTPADNIH VODA}

Predložen je teorijski model potenciometrijskih titracionih krivih natrijum-dodecil-sulfata (anjonski tenzid) $i$ ispitane su odzivne karakteristike dva tenzidna senzora (komercijalnog i sopstvene konstrukcije). Oba senzora korišćena su za generisanje potenciometrijskih eksperimentalnih podataka, koji su upotrebljeni u izračunavanjima pomoću jednačina bilansa mase i naelektrisanja. Eksperimentalni podaci upoređeni su sa odgovarajućim teorijskim krivama u kojima su odzivni parametri senzora (nagib $S$, faktor konstantnog potencijala $E_{0}$, potenciometrijski koeficijent selektivnosti $K_{i, j}^{\text {pot }}$ ), parametri membrane senzora (konstanta proizvoda rastvorljivosti $K_{S, \text { CatAn }}$ i svojstva analita (aktivitet $a_{\mathrm{i}}$, koncentracija $c_{\mathrm{i}}$ ), određeni $i$ optimizovani pomoću Solver aplikacije (Excel programski paket).

Ključne reči: tenzidni senzor, tenzidi, potenciometrija, modelovanje, solver

Originalni naučni rad

Primljeno za publikovanje: 10. 07. 2013.

Prihvaćeno za publikovanje: 23. 09. 2013 